\title{
Effects of Strategic Performance Appraisal, Career Planning and Employee Participation on Organizational Commitment:
}

\section{An Empirical Study}

\author{
Danlami Sani Abdulkadir \\ Department of Business Administration, Ibrahim Badamasi Babangida University, Lapai, Nigeria \\ Tel: 234-805-512-3596_E-mail: abdulkadirdanlami@yahoo.com
}

Sulu Babaita Isiaka

Department of Business Administration, University of Ilorin, Ilorin, Nigeria

Tel: 234-805-302-2587Ｅ-mail: sibyaka@yahoo.com

Salami Isaac Adedoyin

Department of Business Administration, Kwara State Polytechnic, Ilorin, Nigeria

Tel: 234-805-058-9020Ｅ-mail: adedoyin.Isaac@yahoo.com

Received: January 15, 2012

Accepted: February 16, 2012

Published: April 1, 2012

doi:10.5539/ibr.v5n4p124

URL: http://dx.doi.org/10.5539/ibr.v5n4p124

\begin{abstract}
Despite the recent research efforts into the antecedents of organizational commitment most especially in the developed economies, little empirical work has been conducted examining the effect of some human resource management practices such as performance appraisal system, career planning system and employee participation on organizational commitment. In this article, we examined the effect of these human resource management practices in explaining employee job commitment in the Nigerian banking sector. Based on a survey of 14 banks in Nigeria, the study applies regression analysis, correlation analysis and G-test in testing the hypotheses. Results indicate that performance appraisal system, career planning system and employee participation significantly influence employee job commitment and that the level of organizational commitment of employees in the Nigerian banking sector is low. The study therefore, recommends that for employees to be genuinely committed to their jobs, organizations should make conscious efforts at strategically managing performance appraisal, career planning and employee participation with a view to ensuring effective implementation and achieving desired results.
\end{abstract}

Keywords: Performance appraisal, Career planning, Employee participation, Organizational commitment

\section{Introduction}

One of the most important success factors in today's turbulent and competitive business environment is an energetic, competent, motivated, productive and highly committed and innovative human resource. With the realization that Human Resource (HR) is indeed an organization's valuable asset and hence, a source of competitive advantage, there is a need for organizations to address the effectiveness of their employee participation in decision making, performance appraisal and career planning systems as well as how responsive these practices are in enhancing job commitment of employees. The success, survival and competing power of organizations depend on the commitment of their members, and this may to a large extent depend on how satisfied the employees are in respect of the organization's appraisal mechanism, extent of participation in decision making as well as career planning strategies. The concept of organizational commitment therefore, plays an important role in HRM philosophy. As Guest (1987) puts it, HRM policies are designed to 'maximize organizational integration, employee commitment, flexibility and quality of work'.

There is a need to understand the linkage between individuals and organizations in terms of conceptual framework of organizational commitment. Organizational commitment has been widely described in the management and behavioural sciences literature as a key factor in the relationship between individuals and organizations. For 
example, it has been described as the factor that promotes the attachment of the individual to the organization (Raju \& Srivastava, 1994). Employees who willingly continue their association with the organization and devote considerable effort to achieving organizational goals could therefore, be regarded as been committed to the organization.

The issue of organizational commitment takes on increased importance due to its link with propensity to leave and turnover (Brown \& Peterson, 1993). While there have been many proposed antecedents to organizational commitment, human resource management practices such as: employee participation, performance appraisal and career planning systems have received little or no attention in determining the precursors of organizational commitment. Hence, the broad objective of this study is to examine the effect of strategic performance appraisal, career planning systems and employee participation on organizational commitment of banks' employees in Nigeria. Other specific objectives of the study are to: (i) examine the extent of job commitment of banks' employees in Nigeria and (ii) examine the degree of relationships between organizational commitment and employee participation, performance appraisal and career planning systems in the Nigerian banking sector.

\section{Literature Review}

\subsection{Theoretical Framework}

\subsubsection{Organizational Commitment}

Organizational commitment is the relative strength of the individual's identification with, and involvement in, a particular organization. It consists of three factors as highlighted by Armstrong (2006):

i. a strong desire to remain a member of the organization;

ii. a strong belief in, and acceptance of, the values and goals of the organization; and

iii. a readiness to exert considerable effort on behalf of the organization.

An alternative definition of organizational commitment emphasizes the importance of emotions, costs and personal values in creating commitment. Meyer and Allen (1993) identified and defined three components of organizational commitment as follows:

\section{i. Affective Commitment \\ ii. Continuance Commitment \\ iii. Normative Commitment}

These three components of commitment are alternatively described by Brief (1998) as the product of (i) emotional attachments (affective commitment), (ii) the costs of leaving, such as losing attractive benefits or seniority (continuance commitment) and (iii) the individual personal values (normative commitment).

According to Meyer and Allen (1993), affective commitment is concerned with employees' attachment to, identification with and involvement in the organization. It therefore, follows that; affective commitment to the organization could be characterized by a sharing the values, a desire to maintain membership and working without any expectations for the benefit of the organization. In consequence of the affective commitment, employees want to maintain their memberships in the organization (Dawley et al., 2005). Affective commitment refers to feelings of belonging and sense of attachment to the organization and it has been related to personal characteristics, organizational structures, and work experiences, for example; pay, supervision, role clarity and skill variety (Hartmann, 2000).

Continuance commitment on the other hand refers to employees' assessment of whether the costs of leaving the organization are greater than the costs of staying. Employees who perceive that the costs of leaving the organization are greater than the costs of staying remain because they need to. In other words, individuals do not leave a company for fear of losing their benefits, taking a pay cut, and not being able to find another job (Murray et al., 1991).

Normative commitment refers to an employee's feelings of obligation to remain with the organization. According to Meyer and Allen's (1991), the individual commits to and remains with an organization because of feelings of obligation. These feelings may be derived from many sources. For example, the organization may have invested resources in training an employee who then feels a 'moral' obligation to put forth effort on the job and stay with the organization to 'repay the debt.' It may also reflect an internalized norm, developed before the person joins the organization through family or other socialization processes, that one should be loyal to one's organization.

\subsubsection{Performance Appraisal System}

Virtually all organizations have some formal or informal means of appraising their employees' performance. Dessler (2008) defined performance appraisal as any procedure that involves (i) setting work standards, (ii) assessing the 
employee's actual performance relative to those standards, and (iii) providing feedback to the employee with the aim of motivating him or her to eliminate performance deficiencies or to continue to perform above par.

Organizations can therefore, monitor the development of desired employee attitudes and behavious through the use of the appraisal mechanisms. This appraisal-based information could be used for changing the selection and training practices to select and develop employees with the desired behavious and attitudes. However, the effectiveness of skilled employees will be limited unless they are motivated to perform their jobs.

\subsubsection{Career Planning System}

Career planning is the deliberate process through which someone becomes aware of his or her personal skills, interests, knowledge, motivations, and other characteristics; acquires information about opportunities and choices; identifies career-related goals; and establishes action plans to attain specific goals (Dessler, 2008). A well-functioning career planning system may encourage employees to take more responsibility for their own development, including the development of the skills viewed as critical in the company (Doyle, 1997). A well-planned career development system along with internal advancement opportunities based on merit, results in high motivation among employees, which has an impact on firm performance (Milkovich \& Boudreau, 1998).

\subsubsection{Employee Participation}

Participation is about employees playing a greater role in the decision making process. It is an arrangement that ensure that employees are given the opportunity to influence management decisions and to contribute to the improvement of organizational performance (Armstrong, 2006). The degree of participation by non-managerial employees in decision making varies from one organization to another. Studies have however shown that employee participation is positively related to performance, satisfaction, and productivity of an employee (Pfeffer, 1994; Verma, 1995). The purposes of employee participation have been defined by Marchington et al. (2001) as:

a. articulation of individual dissatisfaction - to rectify a problem with management or prevent deterioration of relations;

b. expression of collective organization - to provide a countervailing source of power to management;

c. contribution to management decision making - to seek improvements in work organization, quality and productivity; and

d. demonstration of mutuality and cooperative relations - to achieve long term viability for the organization and its employees.

\subsection{Previous Research}

Studies linking performance appraisal, career planning and employee participation with organizational commitment are relatively too scanty. Hence, in this study, we presented some empirical findings linking organizational commitment with some related constructs or concepts such as leadership styles, intention to leave and job satisfaction.

Human resources management practices, leadership styles and trust within the organization are some of the organizational factors that have been associated with organizational commitment (Meyer \& Allen, 1997).

In nine studies involving 2734 persons, Dunham et al. (1994) examined how participatory management and supervisory feedback influenced employee levels of affective, continuance, and normative commitment. The researchers found that when supervisors provided feedback about performance and allowed employees to participate in decision-making, employee levels of affective commitment was stronger than both continuance and normative. That is, employees indicated staying with the organization was more related to wanting to, rather than needing to or feeling they ought to.

In a study of 238 nurses, Cohen (1996) investigated the relationship between affective, continuance, and normative commitment and the following other types of commitment: work involvement, job involvement, and career commitment. Findings revealed that affective commitment was more highly correlated with all the other types of commitment. In other words, employees who remained with the organization because they wanted to were more likely to exhibit higher levels of commitment to their work, their job, and their career.

Importance of training in developing committed employees cannot be ignored. Training generates a feeling of belonginess among employees. Likewise executive development programme also seems to be a platform of producing committed employees. Lam and Zhang (2003) conducted a study and found that expectations are normally unmet, and job characteristics, training and development, and compensation and fairness are related to 
satisfaction and commitment. Loui (1995) also found that commitment was significantly related to trust, job involvement, and job satisfaction.

Blau (1985) examined the relationship between leadership style and commitment and found that a consideration leadership style was found to have a greater influence than task-oriented style on commitment. Organizational commitment provides a platform to employees in terms of staying in the organization. Mueller et al. (1994) found that organizational commitment is a better predictor of intention to stay and thus turnover intentions than job satisfaction.

Taunton et al. (1997) reported an indirect relationship between organizational commitment and turnover intentions and stated that organizational commitment was a stronger predictor of turnover intentions than job satisfaction in their causal model.

Moynihan et al. (2000) hypothesized that job satisfaction and affective commitment would positive association with general performance and leadership while continuance commitment would exhibit a negative association. As predicted, job satisfaction associated positively with performance, though not with leadership. Continuance commitment negatively associated with both performance and leadership. Increased organizational commitment has also been positively associated with valuable organizational outcomes, including job performance ratings, decreased intention to search for new jobs and reduced turnover intentions (Bergmann et al., 2000).

Few behavioral scientists believe that for generating commitment organizational support is also a key factor. Yoona (2002) proposed a new dual-process model of organizational commitment. The model stipulates that overall job satisfaction and perceptions of organizational support are key emotional and cognitive processes that mobilize commitment in the workplace. The model also suggests that the feelings of job satisfaction and perceptions of organizational support operate through independent channels to mediate the impact of work experiences on organizational commitment.

Irving et al. (1997) investigated the relationship between affective, continuance, and normative commitment and the outcome measures of job satisfaction and turnover intentions. Total participants for the study included 232 employees. Results revealed that job satisfaction was positively related to both affective and normative commitment. However, job satisfaction was negatively related to continuance commitment. All three types of commitment were negatively related to turnover intentions, with continuance commitment having the strongest negative relationship.

Cohen and Kirchmeyer (1995) undertook a study to investigate the relationship between affective, continuance, and normative commitment and the non-work measure of resource enrichment. Their participants included 227 nurses from two hospitals. The researchers found positive relationships between resource enrichment and both affective and normative commitment. However, the relationship between continuance commitment and resource enrichment was negative. In effect, employees who were staying with the organization because they wanted to or felt they ought to, indicated higher involvement and enjoyment with work activities. Whereas, employees who were staying with the organization because they felt they needed to indicated less involvement and dissatisfaction with work activities.

\section{Conceptual Framework and Hypotheses Development}

Based on the above literature on performance appraisal, career planning, employee participation and organizational commitment, the following model was developed. The cornerstone of the model is tied around the fact that effective performance appraisal, career planning, employee participation would lead to an increased level of employee job commitment. The model is presented in Figure 1.

In order to achieve the objectives designed for this study, the following research hypotheses are stated in their null form based on the revelations in the review of literature concerning performance appraisal, career planning, employee participation and organizational commitment:

Hypothesis One:

Performance appraisal, career planning and employee participation have no significant effect on organizational commitment.

Hypothesis Two:

The level of organizational commitment in the Nigerian banking sector is low.

Hypothesis Three:

There is no significant relationship between organizational commitment and performance appraisal, career planning and employee participation. 


\section{Methodology}

\subsection{Population and Sampling Technique}

The population of the study is made up of the 24 mega banks in Nigeria. The study specifically made use of a sampling frame consisting of 21 banks that were quoted on the Nigerian Stock Exchange (NSE) as at $1^{\text {st }}$ May, 2011. The sample size of the study was computed to be 19 banks using the formula as suggested by Guilford and Flruchter (1973) for estimating sample size. Using simple random sampling technique, data was collected through the use of a structured questionnaire.

The unit of analysis in this study was the firm and multi-rater response approach was adopted. Three questionnaires were therefore sent to each company and address to the head of HR department who was required to be one of the respondents. Since the unit of analysis is the firm, the scores for each variable were aggregated and average over the three respondents for each company. For companies where the number of expected respondents is less than three, the average scores of the actual respondents were taken for each variable.

\subsection{Analytical Techniques}

Data collected was subjected to descriptive statistics, correlational analysis and multiple regression analysis. In order to gain perspectives into the socio-economic and demographic characteristics of respondents, frequency distribution of responses was calculated. G-test was used in ascertaining whether or not there is a significant difference between the observed level of organizational commitment and their expected values. While regression analysis was used to determine the predictor powers of performance appraisal, career planning and employee participation on organizational commitment, correlation analysis on the hand was used to show the relationship between the dependent and independent variables.

\subsection{Measures}

In this study, items used to operationalize performance appraisal, career planning, employee participation and organizational commitment were from previous validated measures and refined by the author to suit the purpose of this study.

Organizational commitment was measured using Meyer and Allen's (1997) Organizational Commitment Questionnaire (OCQ). It was modified by the author to suit the present study. Overall, organizational commitment was measured by an instrument having 15 items, each rated on a 5-point scale.

Performance appraisal, career planning and employee participation were all measured using previously validated scales (Singh, 2004; Som, 2008; Abdulkadir, 2012).

Performance appraisal was measured through an 8 -item scale. The respondents were asked to indicate the extent to which performance is evaluated on the basis of quantifiable results and usage of performance appraisal data. In other words, they were to indicate on a scale of 1 'strongly disagree' to 5 'strongly agree' their agreement with some performance appraisal system practices in their organizations. A sample item was 'performance of the employees is measured on the basis of objective quantifiable results'.

Career planning system variable was measured by an instrument having 7 items, each rated on a 5-point scale. The respondents were asked to indicate on a scale of 1 'strongly disagree' to 5 'strongly agree' the clarity and usage of career planning system in their organizations. A sample item is 'our company provides clear career path information to employees'.

Employee participation was measured through a 3-item scale. The respondents were asked to indicate on a scale of 1 'strongly disagree to 5 'strongly agree' the extent to which superiors allow employees to participate in operations decisions as well as the opportunity given to suggest improvements in the way things are done. A sample item is 'employees in this company are provided opportunity to suggest improvements in the ways things are done'.

\subsection{The Study Model}

The study model which was based on the study's conceptual framework is presented below:

Organizational Commitment $=f($ Performance Appraisal, Career Planning, Employee Participation $)$

$$
\begin{gathered}
O C=f(P A, C P, E P) \\
O C=\beta_{0}+P A S \beta_{1}+C P S \beta_{2}+E P \beta_{3}+e
\end{gathered}
$$

Where, $O C=$ Organizational Commitment; $P A S=$ Performance Appraisal System; $C P S=$ Career Planning System; $E P=$ Employee Participation; $\beta_{0}=$ constant term; $\beta_{1}, \beta_{2}$ and $\beta_{3}=$ coefficients of performance appraisal, career planning and employee participation respectively, and $\mathrm{e}=$ error term. 


\section{Results}

\subsection{Demographic Characteristics of the Respondents}

Out of a set of fifty seven (57) questionnaires that were administered to nineteen (19) companies, 34 copies of questionnaire from 14 companies were dully completed and returned. This represented about $60 \%$ response rate.

The analysis is therefore, based on a set of thirty four (34) copies of questionnaire that were returned and found suitable for analysis. The detailed analysis of the demographic characteristics of the respondents is therefore, presented in Table 1 below:

The table shows that of the 34 respondents $22(65 \%)$ are within the rank of Assistant Managers and above while $35 \%$ are below the managerial position. This gives an indication that the respondents are highly rated employees. $35 \%$ of the respondents are based in the Human Resource Department s of their respective organizations. Those working in the Marketing and Operations departments represent about $24 \%$ and $30 \%$ respectively. Four (4) respondents representing $11 \%$ are working in other departments such as risk management, legal and other supporting units of their respective organizations.

Majority of the respondents 25 (75\%) had put in at least four (4) years of service. This is an indication that the respondents have actually spent enough time in the service to know how the subject matter of this study could affect them. $58 \%$ of the respondents are male, while $14 \%$ are females. Thirty two (32) respondents representing about (84 \%) are over 35 years old. The mean age of the respondents is 46.4 years.

\subsection{Reliability and Validity}

Cronbach alpha reliability test and item-to-total correlation were computed in order to address issues of common method variance and to assess the internal consistency of the multiple scales. Items having low item-to-total correlation may signal that the items do not reflect the particular construct or might have tapped into another dimension of the construct.

From our computations in Table 2 above, the Cronbach alpha of 0.92 is above the minimum threshold of 0.70 as suggested by Nunally and Bernstein (1994), while item-to-total correlations were well above the recommended value of 0.5 (Hair et al., 2005). The result therefore, indicates high internal consistency of the scales.

\subsection{Test of Hypotheses}

Of the 57 questionnaires distributed to nineteen (19) banks, we received a total of 34 completed and usable questionnaires representing a response rate of about $60 \%$.

\section{Hypothesis One:}

Performance appraisal, career planning and employee participation have no significant effect on organizational commitment.

Results indicate that performance appraisal, career planning and employee participation have significant effect on organizational commitment with a multiple correlation $(R)$ of 0.84 and an adjusted $R^{2}$ of 0.63 . This implies that about $63 \%$ of the variation in organizational commitment is adequately explained by the independent variables i.e. performance appraisal, career planning and employee participation. The standardized coefficients of performance appraisal, career planning and employee participation are presented in Table 3 below. This result has thus, provided support for alternative hypotheses one.

Hypothesis Two:

The level of organizational commitment in the Nigerian banking sector is low.

The mean score of organizational commitment was 41.21 out of a possible maximum score of 75 thus, indicating a moderate (54.9\%) extent of employee job commitment in the Nigerian banking sector.

To test the significance of the extent of employee job commitment in the Nigerian banking sector, we computed a G-test with objective of ascertaining whether the extent of organizational commitment as given above significantly differ from the expected extent of commitment. We assert that for strategic HRM to be said to be at least moderately practice in the Nigerian banking sector, the extent of organizational commitment should not be less than $55 \%$ hence; expected values used in the computation of G-test is $55 \%$.

The critical value of $\mathrm{X}^{2}$ for degree of freedom of $13(\mathrm{~N}-1)$ at $95 \%$ level of confidence is 22.36 . Since the empirical value (i.e. the computed value of G) is 9.039 and it is less than the critical value of 22.36 , then the result is statistically insignificant. We therefore, accept the null hypothesis $\left(\mathrm{H}_{0}\right)$ which states the level of organizational commitment in the Nigerian banking sector is low. 


\section{Hypothesis Three:}

There is no significant relationship between organizational commitment and performance appraisal, career planning and employee participation.

As shown in Table 4 above, there is a significant positive relationship between performance appraisal system and organizational commitment with a zero-order correlation of 0.57 . Similarly, career planning system and employee participation were also found to have a significant positive relationship with organizational commitment with correlations of 0.59 and 0.63 respectively.

Overall, the above results provide support for the alternative hypothesis which asserts that there is a significant positive relationship between performance appraisal system, career planning system, employee participation and organizational commitment.

\section{Discussion of Findings}

The main objective of this study is to examine the effect of performance appraisal, career planning and employee participation on organizational commitment among other key specific objectives. The results of this study have confirmed to some extent that performance appraisal, career planning and employee participation are major antecedents of organizational commitment. The results indicate that performance appraisal, career planning and employee participation all have significant positive effects on organizational commitment. This implies that the higher the levels of these HR practices, the higher the level of employee job commitment and hence, organizational commitment.

Our results also show that the level of organizational commitment in the Nigerian banking sector is low. This has to some extent confirmed our hypothesis that asserted that employees in the Nigerian banking sector are not fully committed to their jobs vis-à-vis their organizations.

Results also indicated that organizational commitment is positively related to employee performance appraisal, career planning and employee participation. It therefore, implies that the higher the level of performance appraisal, career planning and employee participation, the higher the level of organizational commitment.

\section{Conclusions and Recommendations}

The results of this study have indicated that performance appraisal, career planning and employee participation have positive effect on organizational commitment and that the level of organizational commitment in the Nigerian banking sector is low. The results have, to a large extent, provided evidence for the value added by performance appraisal, career planning and employee participation in enhancing organizational commitment. Be that as it may, questions still need to be asked about the low level of employee job commitment in the Nigerian baking sector. Can this be pass-off as a problem of data specification or even procedure? Or can it be attributed to factors other than performance appraisal, career planning and employee participation? These, I believed, are questions that can be resolved under different settings.

However, for employees to be genuinely committed to their organizations, the study recommends that organizations should make conscious efforts at strategically managing performance appraisal, career planning and employee participation with a view to ensuring effective implementation. This can be achieved through ensuring that:

a. employees have faith in the performance appraisal system;

b. appraisal system has a strong influence on individual and team behaviour;

c. the organization provides a clear career path information to employees;

d. the organization plans for the career and development of employees;

e. that employees are provided opportunity to suggest improvement in the ways things are done.

\section{References}

Armstrong, M. (2006). A Handbook of Human Resource Management Practice (10th ed.). London: Kogan Page.

Bergmann, T. J., Lester, S. W., De Meuse, K. P., \& Grahn, J. L. (2000). Integrating the three domains of employee commitment: An exploratory study. Journal of Applied Business Research, 16(4), 15-26.

Blau, G. (1985). The measurement and prediction of career commitment. Journal of Occupational Psychology, 58, 277-88. http://dx.doi.org/10.1111/j.2044-8325.1985.tb00201.x

Brief, A. P. (1998). Attitudes In and Around the Organizations. Thousand Oaks, CA: Sage. 
Brown, S. P., \& Peterson, R. A. (1993). Antecedents and consequences of salesperson job satisfaction: Meta-Analysis and assessment of causal effects. Journal of Marketing Research, 30(1), 63-77. http://dx.doi.org/10.2307/3172514

Cohen, A. (1996). On the discriminant validity of the meyer and Allen Measure of organizational commitment: How does it fit with the work commitment construct?. Educational and Psychological Measurement, 56, 494-503. http://dx.doi.org/10.1177/0013164496056003011

Cohen, A., \& Kirchmeyer, C. (1995). A multidimensional approach to the relations between organizational commitment and nonwork participation. Journal of Vocational Behavior, 46, 189-202. http://dx.doi.org/10.1006/jvbe.1995.1012

Dawley, D., Stephens, R., \& Stephens, D. (2005). Dimensionality of organizational commitment in volunteer workers: Chamber of commerce board members and role fulfillment. Journal of vocational Behavior, 67, 511-525. http://dx.doi.org/10.1016/j.jvb.2004.09.001

Dessler, G. (2008). Human Resource Management (11th Ed.). New Jersey: Prentice Hall.

Doyle, M. (1997). Management Development. In I. Beardwell \& L. Holden (Eds.), Human Resource Management: A Contemporary Perspectives (pp 212-35). London: Pitman.

Dunham, R., Grube, J., \& Castaneda, M. (1994). Organizational commitment: The utility of an integrative definition. Journal of Applied Psychology, 79, 370-380. http://dx.doi.org/10.1037/0021-9010.79.3.370

Guest, D. E. (1987). Human resource management and industrial relations. Journal of Management Studies, 14(5), 503-521. http://dx.doi.org/10.1111/j.1467-6486.1987.tb00460.x

Hair, J. F., Anderson, R. E., Tatham, R. L., \& Black, W. C. (2006). Multivariate Data Analysis. New Jersey: Prentice Hall International, Inc.

Hartman, C. C. (2000). Organizational commitment: Method scale analysis and test of effects. International Journal of Organizational Analysis, 8, 89-109. http://dx.doi.org/10.1108/eb028912

Irving, P., Coleman, D., \& Cooper, C. (1997). Further assessments of a three-component model of occupational commitment: Generalizability and differences across occupations. Journal of Applied Psychology, 82(3), 444-452. http://dx.doi.org/10.1037/0021-9010.82.3.444

Loui, K. (1995). Understanding employee commitment in the public organization: A study of the Juvenile Detention

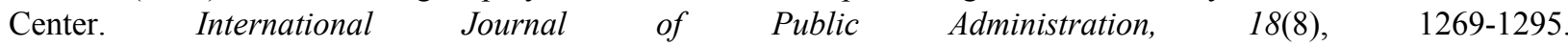
http://dx.doi.org/10.1080/01900699508525052

Marchington, M., Wilkinson, A., Ackers, P., \& Dundon, A. (2001). Management Choice and Employee Voice. London: CIPD.

Meyer, J. P., \& Allen, N. J. (1991). A Three-component conceptualization of organizational commitment. Human Resource Management Review, 1(1), 61-89. http://dx.doi.org/10.1016/1053-4822(91)90011-Z

Meyer, J. P., \& Allen, N. J. (1993). A three component conceptualization of organizational commitment. Human Resource Management Review, 1, 61-98. http://dx.doi.org/10.1016/1053-4822(91)90011-Z

Meyer, J. P., \& Allen, N. J. (1997). Commitment in the Workplace. Thousand Oaks, CA: Sage Publications.

Milkovich, T. G., \& Boudreau, W. J. (1998). Human Resource Management (8th ed.). Boston: Irwin.

Moynihan, L. M., Boswell, W. R., \& Boudreau, W. J. (2000). The influence of job satisfaction and organizational commitment on executive withdrawal and performance. CAHRS Working Paper 300-16. Ithaca, NY: Cornell University, School of Industrial and Labor Relations, Center for Advanced Human Resource Studies.

Mueller, C. W., Boyer, E. M., Price, J. L., \& Iverson, R. D. (1994). Employee attachment and noncoercive conditions of work: The case of dental hygienists. Work and Occupations, 21(2), 179-212. http://dx.doi.org/10.1177/0730888494021002002

Murray, L. P., Gregoire, M. B., \& Downey, R. G. (1991). Organizational commitment of management employees in restaurant operations. Hospitality Research Journal, 14, 339-348.

Nunally, J. C., \& Bernstein, I. H. (1994). Psychometric Theory. New York: McGraw-Hill.

Pfeiffer, J. (1994). Competitive Advantage through People. Boston: Harvard Business School Press.

Raju, P. M., \& Srivastava, R. C. (1994). Factors contributing to commitment to the teaching profession. International Journal of Educational Management, 8(5), 7-13. http://dx.doi.org/10.1108/09513549410065684 
Singh, K. (2004). Impact of human resource practices on perceived firm performance in Indian. Asia Pacific Journal of Human Resources, 42, 301-317. http://dx.doi.org/10.1177/1038411104048170

Som, A. (2008). Innovative human resource management and corporate performance in the context of economic liberalization in India. Thunderbird International Business Review, 49(2), 1-33.

Taunton, R. L., Boyle, D. K., Woods, C. Q., Hansen, H. E., \& Bott, M. J. (1997). Manager leadership and retention of hospital staff nurses. Western Journal of Nursing Research, 19(2), 205-226. http://dx.doi.org/10.1177/019394599701900206

Verma, A. (1995). Employee Involvement in the Workplace. In M. Gunderson \& A. Ponak (Eds.), Research in Personnel and Human Resource Management. New Haven, CT: JAI Press.

Yoona, E. (2002). Dual process model of organizational commitment, Job satisfaction and organizational support. Work and Occupations, 29(1), 97-124. http://dx.doi.org/10.1177/0730888402029001005

Table 1. Demographic Characteristics of the Respondents $(\mathrm{N}=34)$

\begin{tabular}{|c|c|c|}
\hline Characteristics & Frequency & Percentage (\%) \\
\hline \multicolumn{3}{|l|}{ Job Title } \\
\hline Senior Managers \& Above & 8 & 25 \\
\hline Asst. Managers/Managers & 14 & 40 \\
\hline Others & 12 & 35 \\
\hline Total & 34 & 100 \\
\hline \multicolumn{3}{|l|}{ Departments } \\
\hline Human Resource & 12 & 35 \\
\hline Marketing & 8 & 24 \\
\hline Operations & 10 & 30 \\
\hline Others & 4 & 11 \\
\hline Total & 34 & 100 \\
\hline \multicolumn{3}{|l|}{ Length of Service } \\
\hline Less than 1 Year & 2 & 5 \\
\hline 1-3 Years & 7 & 20 \\
\hline 4-5 Years & 14 & 43 \\
\hline 5 Years \& Above & 11 & 32 \\
\hline Total & 34 & 100 \\
\hline \multicolumn{3}{|l|}{ Sex } \\
\hline Male & 20 & 58 \\
\hline Female & 14 & 42 \\
\hline Total & 34 & 100 \\
\hline \multicolumn{3}{|l|}{ Age } \\
\hline 30-35 Years & 2 & 6 \\
\hline 36-45 Years & 14 & 42 \\
\hline 46-55 Years & 13 & 37 \\
\hline 56 Years \& Above & 5 & 15 \\
\hline Total & 34 & 100 \\
\hline
\end{tabular}

Source: Author's Computations, 2012.

Table 2. Descriptive Statistics and Item-to-Total Correlations

\begin{tabular}{llll}
\hline & Mean & Std. Deviation & Item-to total Correlations \\
\hline Performance Appraisal System & 28.43 & 2.74 & .885 \\
Career Planning System & 26.14 & 2.63 & .906 \\
Employee Participation & 10.71 & 0.91 & .707 \\
Organizational Commitment & 41.21 & 5.95 & .830 \\
\hline
\end{tabular}

Source: Author's Computations Using SPSS, 2012. 
Table 3. Results of Standardized Regression Model

\begin{tabular}{lll}
\hline & Standardized Coefficients & t-values \\
\hline Performance Appraisal System & 0.463 & 0.434 \\
Career Planning System & 0.131 & 0.116 \\
Employee Participation & 0.339 & 1.414 \\
$\mathrm{R}$ & 0.844 & \\
$\mathrm{R}^{2}$ & 0.627 & \\
$\mathrm{~F}$ - value & $8.288^{*}$ & \\
\hline
\end{tabular}

Note: ${ }^{*}$ Significant at the 0.05 level.

Source: Author's Computations Using SPSS, 2012.

Table 4. Correlation Matrix of the Measurement Variables

\begin{tabular}{|c|c|c|c|c|}
\hline Variables & 1 & 2 & 3 & 4 \\
\hline Career Planning System & & 1.00 & $.54^{*}$ & $.59^{* *}$ \\
\hline Organizational Commitment & & & & 1.00 \\
\hline
\end{tabular}

Note: ${ }^{* *}$ significant at the 0.01 level; ${ }^{*}$ significant at the 0.05 level.

Source: Author's Conceptualization, 2012.

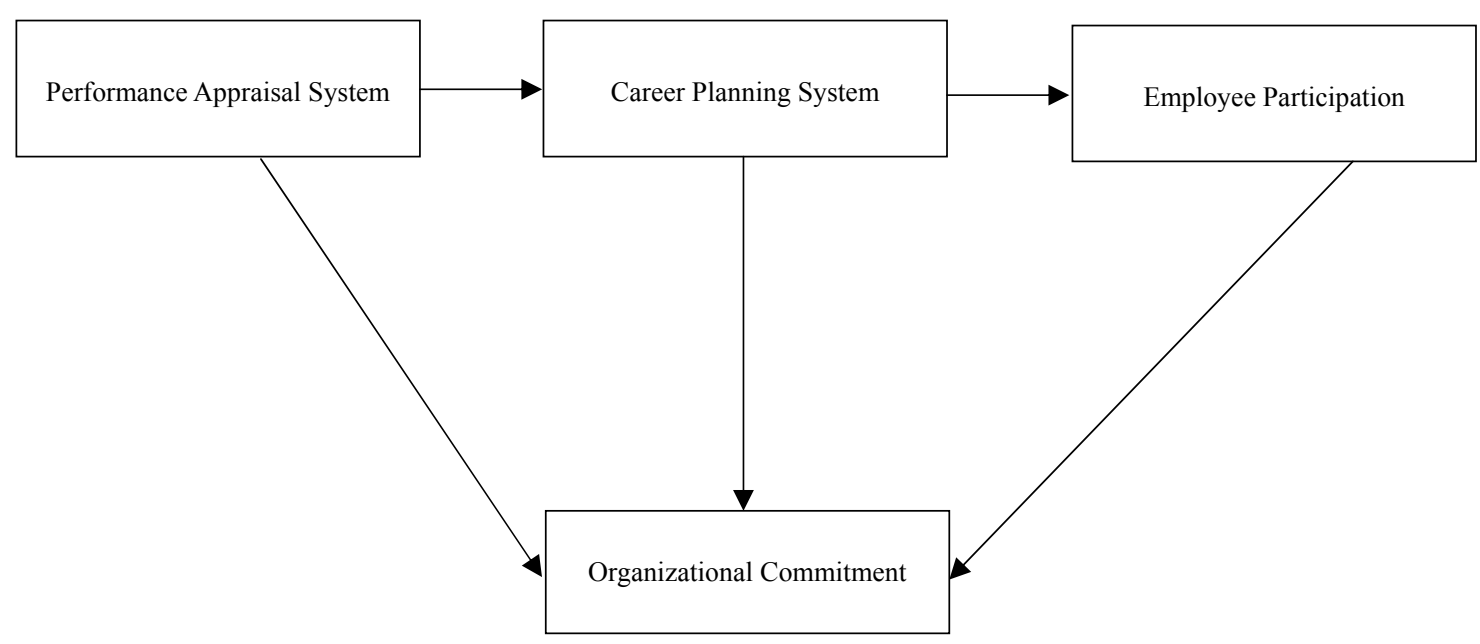

Figure 1. Conceptual Framework

Source: Author's Conceptualization, 2012. 